学術論文

\title{
頭部装用型ウェアラブル機器間の人体通信モデルと電極構造
}

\section{Modeling and Electrodes Design for Human Body Communication in Head-Mounted Wearable Devices}

\author{
村松 大陸(学生員)，横山 義晃，佐々木 健
}

\author{
Dairoku MURAMATSU (Stu. Mem.), Yoshiaki YOKOYAMA, Ken SASAKI
}

\begin{abstract}
Human body communication, which utilizes our body as part of the transmission medium, has received a lot of attention as a promising wireless technology for body area network such as communication in head-mounted wearable devices. In this paper, input impedance characteristics of transceiver electrodes, transmission characteristics and electric field distributions around the head model were investigated through an electromagnetic field analysis for clarify a transmission mechanism of human body communication between head-mounted wearable devices. The analysis results showed that the signal frequency had little effect on the transmission characteristics and electric field distributions in the frequency of 10, 20, $30 \mathrm{MHz}$. However, it was found that the transmission mechanism between head-mounted wearable devices is influenced by the number of electrode of transceiver. Moreover, impedance matched transceiver was designed for improving the transmission characteristics. These results suggest that the optimized transceiver can realize the human body communication with low-power consumption and low electromagnetic exposure for human.
\end{abstract}

Keywords: human body communication, body area network, wearable device, electromagnetic field analysis, electrode, impedance matching

\section{1 はじめに}

近年の高密度集積化技術の進歩にともない，情報通 信機器はモバイルからウェアラブルへと進化し，複数 のウェアラブル機器を身につけ，人体近傍でネットワ ークを構築する BAN (Body Area Network)[1]の構想が 現実となりつつある。特に，急速に進展する高齢化社 会におけるウェアラブル機器や BAN の医療・福祉分 野への応用が期待されており，高齢者や障害者の QOL(Quality of Life)向上のために福祉機器が果たす役 割は，今後ますます大きくなると考えられる。BANを 構築する新たな無線通信技術のひとつとして，人体を 高周波信号の伝送路として用いる人体通信[2,3]が注目 を集めている。人体通信は，信号伝送時に周辺の空間 に電磁界がほとんど漏洩しないという特長をもち, ウ エアラブル機器の秘匿性を有した通信方法として有力 視されている。しかしながら，これまでに行われてき た人体通信の伝送メカニズムや機器設計に関する研究 [4-9]は，腕部を対象としたものがほとんどであり，そ の他の人体部位に装着した機器間に関する検討は少な い。本研究では, 補聴器等の頭部に装用寸るウェアラ

連絡先： 村松 大陸 $\overline{\mathbf{T}} 277-8563$ 千葉県柏市柏の葉 5-1-5 東京大学大学院 新領域創成科学研究科人間環境学専攻 佐々木研究室

e-mail: muramatsu@ems.k.u-tokyo.ac.jp

東京大学 新領域創成科学研究科人間環境学専攻
ブル機器間の人体通信に注目した。送受信機の電極構 造および信号周波数の変化による伝送メカニズムの差 異を，FDTD (Finite Difference Time Domain)法を用いた 電磁界解析（米 Remcom 社 : XFdtd）により, 送受信 機電極の入力インピーダンス特性, 送受信機間の伝送 特性，人体周囲の電界分布を計算することで明らかに した。さらに, 検討の結果から, より良好な伝送特性 を実現する送受信機電極構造および機器フロントエン ドのインピーダンスについて提案した。

\section{2 提案する人体通信システム}

補聴器は両耳装用によって, 聞き取りの明瞭度や音 像定位能力が改善されることが明らかとなっている [10]。両耳装用を行う場合, 音場の性質に適応して, 左右の補聴器間でリアルタイムに通信し, 機器装用者 の聞き取り音を最適化するなどの高機能化が望まれて いる。左右側頭部間は, 他の人体部位に比較し可動範 囲が狭いため, 有線接続による通信も考えられる。し かしながら, ウェアラブル機器全般において, 煩雑か つ外見上目立つケーブルを取り除き無線化することは, 機器使用者の QOL を飛躍的に高めることにつながる。 また, 機器の着脱や収納の際に, ケーブル部に負荷が かかることによる断線を防止するためにも，無線化は きわめて有効である。本研究では, 左右補聴器間の通 
信を想定して，側頭部に装着したウェアラブル機器間 の人体通信システムの検討を行った。Fig. 1 に想定す る人体通信システムの構成を示す。ウェアラブル機器 の電極は人体に直に接触するものとする。通信に用い る周波数として, ISM (Industry-Science-Medical)バンド (13.56 MHz)[11]および IEEE 802.15.6 で規定される Wireless BAN 用の $21 \mathrm{MHz}$ および $32 \mathrm{MHz}[12]$ を想定し, $10,20,30 \mathrm{MHz}$ の各周波数で検討を行った。

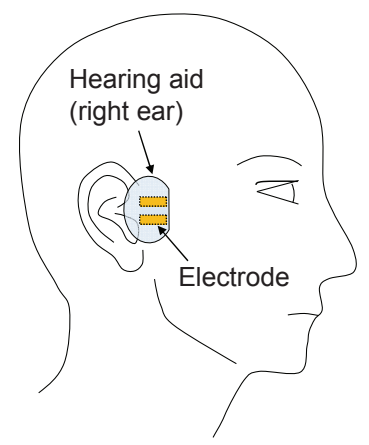

Right lateral face

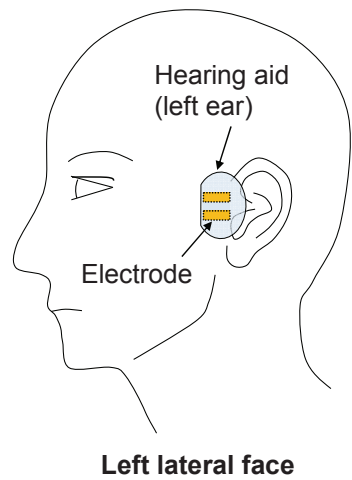

Left lateral face
Fig. 1 Proposed human body communication system.

\section{3 電磁界解析モデル}

\section{1 解析モデル諸元}

本稿では, Zimmerman らが考案した静電結合型の人 体通信方式[3] を参考として, 左右側頭部に装着した ウェアラブル送受信機間の通信を想定した。Fig. 2 に, FDTD 法による電磁界解析に用いる人体頭部モデルを 示す。頭部モデル前面および後面は実形状に近く, 電 界のエッジ効果が生じにくい曲面でモデル化し, 左右 側頭部は電極を接触させるために平面とした。頭部モ デルの寸法は, 日本人の成人男性の平均的な体型を参 考に決定した[13]。また，頭部モデルの媒質はすべて 筋肉とし, Cole-Cole 型分散媒質の電気特性を適用した [14,15]。Table 1 に 10, 20, $30 \mathrm{MHz}$ の各周波数における 筋肉の比誘電率 $\varepsilon_{r}$ および導電率 $\sigma$ を示す。この簡易頭部 モデルは, 解剖学的観点から考えた場合, 筋肉に加え て多数の組織で構成される実人体頭部とは異なる。し かしながら, NICT (独立行政法人 情報通信研究機構) より提供をうけた, 23 の生体組織で構成される詳細頭 部モデル[16]を用いた解析との比較の結果, 簡易頭部 および詳細頭部の両モデルの内部と周囲に生じる電界 分布には十分な類似性を確認している。さらに，均質 モデルの場合には，生体等価ファントムを用いた実験
との比較も可能となる。このため, 本研究における人 体通信の伝送メカニズムの検討には，筋肉均質の簡易 頭部モデルを用いる。

Fig. 3 (A), (B)に, 二電極接触型および一電極接触型 の送受信機電極モデルをそれぞれ示す。二電極モデル は, 回路基板, 信号電極, グラウンド電極, ワイヤ, 励振源 (送信機) もしくは受信負荷 (受信機) で構成 される。一電極モデルは, 二電極モデルからグラウン ド電極を除外した構造とした。送受信機各部の寸法と して, 二電極モデルを人体モデルに接触させた場合に, $10 \mathrm{MHz}$ における電極の入力インピーダンスが $50 \Omega に$ 近くなる $a=8, b=24, d=8, L_{l}=24, L_{2}=24, h=10 \mathrm{~mm}$ を採用 した $[8]$ 。送信機励振源の内部抵抗は $50 \Omega$ とし, 受信機 の負荷は二電極構造の場合 $50 \Omega$, 一電極構造の場合 9 $\mathrm{k} \Omega$ とした。送受信機構成部品はすべて完全導体とした。 FDTD 法の解析領域 $(450$ x 400 x 382 mm) は不均一七 ルで表現しており, 送受信電極周囲を最小の $1 \mathrm{~mm}$, 電極部から離れるにしたがって少しずつ大きくし，最 大で $5 \mathrm{~mm}$ とした。吸収境界としては PML (Perfectly Matched Layer)境界を使用し, その層数は二電極送受信 機の場合に7層, 一電極送受信機の場合に 15 層とした。 また，励振源における入力波形はブロードバンドパル スおよび各周波数の正弦波の二通りとし，回路基板と 信号電極の間にギャップ給電を行った。タイムステッ プは $\mathrm{t}=1.872 \mathrm{ps}$ とした。

Table 1 Electrical properties of the muscle.

\begin{tabular}{lll} 
Frequency $[\mathrm{MHz}]$ & Conductivity $[\mathrm{S} / \mathrm{m}]$ & Relative permittivity \\
\hline 10 & 0.62 & 170 \\
20 & 0.64 & 111 \\
30 & 0.66 & 91.8 \\
\hline
\end{tabular}

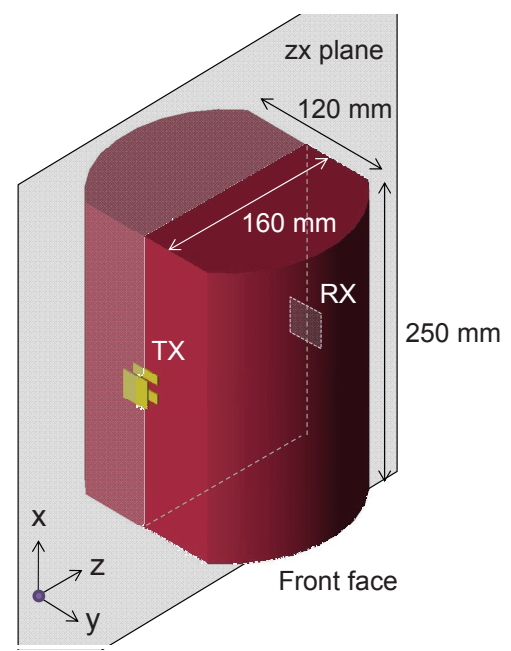

Fig. 2 An analysis model of human head with transceivers. 

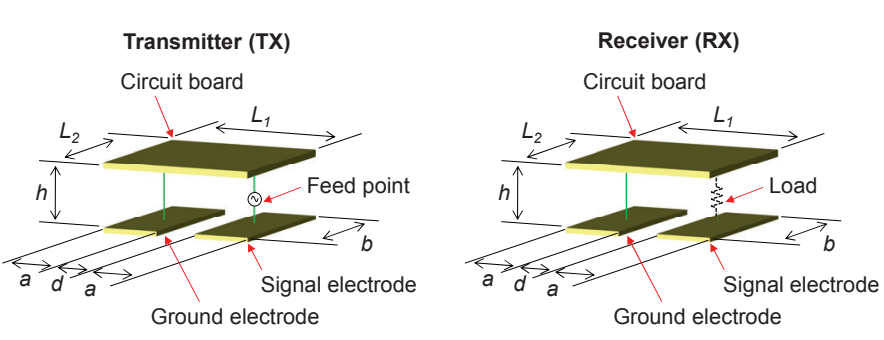

(A) Two electrode transmitter and receiver
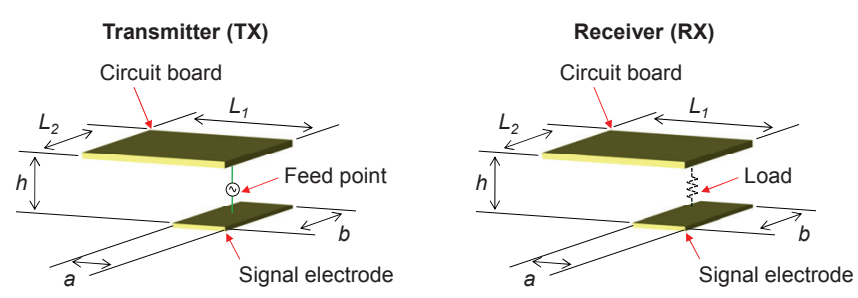

(B) Single electrode transmitter and receiver

Fig. 3 Structure of transmitter and receiver electrode model.

\section{2 体幹の影響}

本稿で対象としている周波数 10 30 MHz における 波長は 30 10 m であり，体長に比較して大きいため, 頭部だけでなく体幹部分も電磁界の分布や伝送特性に 影響を与える可能性がある。ここでは, Fig. 2 に示し た頭部モデルの下部に，簡略化した体幹として 1480 $\times 450 \times 200 \mathrm{~mm}$ の直方体モデルを追加した場合につい て解析を行い, 電極の入力インピーダンス, 送受信機 間の伝送特性, モデル内部および周囲の電界分布に対 する影響の有無について確認した。体幹部分の媒質も, 頭部と同様に筋肉を用いた。送受信機は二電極接触型 とし，送信機励振源の出力インピーダンスおよび受信 機の負荷抵抗はともに $50 \Omega$ とて解析を行った。

Fig. 4 (A)および(B)に，10 MHzにおいて体幹を含め たモデルにより計算される電界分布，頭部モデルのみ で計算される電界分布を示す。電界分布の観察面は,

Fig. 2 に示した送信受信機電極の中央部を横切る zx 面 とした。破線は人体モデルと空間の境界を示している。 Fig. 4 (A)および(B)の電界分布を比較すると, 頭部周囲 の電界強度および分布の状況はほとんど同一であるこ とがわかる。さらに, Table 2 に示すように, 電極の入 カインピーダンス $Z_{\text {in }}$ および送受信機間の伝送特性 $S_{21}$ に関しても体幹の影響はほとんどない。同様の検討を $20 \mathrm{MHz}$ および $30 \mathrm{MHz}$ において行ったところ, $10 \mathrm{MHz}$ の場合と同様に，体幹の影響は無視出来ることが明ら
かになった。以上の結果より，本研究における解析で は，体幹を省略した頭部モデルを用いた。

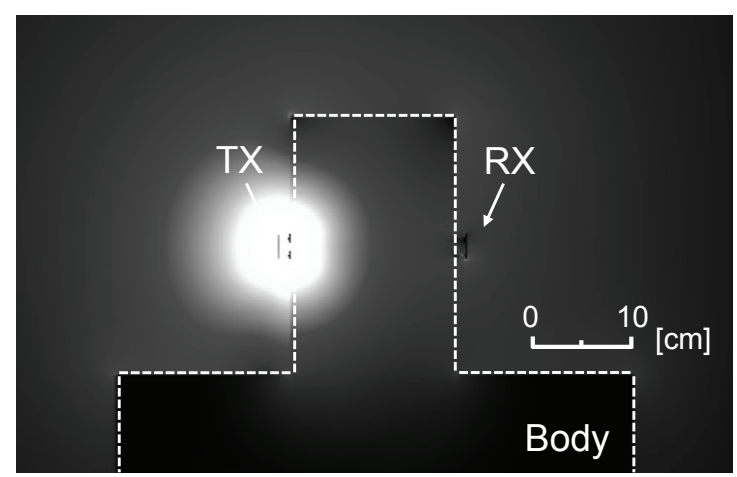

(A) With body

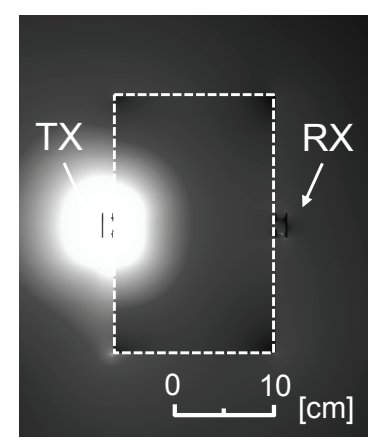

(B) Without body

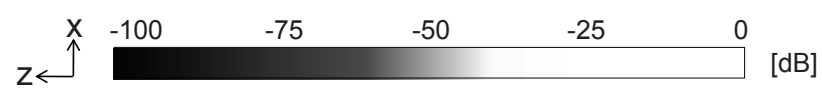

Fig. 4 Electric field distributions around and inside a head model.

Table 2 Comparison between the models with/without body.

\begin{tabular}{llll}
\hline Analysis model & $\operatorname{Re}\left(Z_{\text {in }}\right)[\Omega]$ & $\operatorname{Im}\left(Z_{\text {in }}\right)[\Omega]$ & $S_{21}[\mathrm{~dB}]$ \\
\hline Head with body & 50.9 & -6.75 & -64.5 \\
Head without body & 50.9 & -6.74 & -64.8 \\
\hline
\end{tabular}

\section{4 頭部装用型機器の伝送メカニズム}

人体腕部を利用して，手首に装着した腕時計型機器 と手のひらに配置される情報通信端末との間の人体通 信を行う場合には，二電極送信機と一電極受信機の組 み合わせが伝送効率の点で最適であることが明らかに なっている[8]。しかしながら, 左右側頭部にウェアラ ブル機器を配置し人体通信を行う場合には，送受信機 が人体で隔てられた状態となり，腕部の場合とは伝送 メカニズムや最適な電極構造が異なる可能性がある。 送受信機の電極構造として，Fig. 3(A)に示したような 二電極, または(B)に示したような一電極を人体に接触 
させる構造がこれまでに提案されている。本章では, 左右側頭部に装用されたウェアラブル機器の電極構造 による伝送メカニズムの差異を明らかにするため，二 電極送受信機および一電極送受信機による通信につい て, Fig. 2 の頭部モデルおよび Fig. 3 の電極モデルを用 いて, 送受信機電極の入力インピーダンス, 送受信機 間の伝送特性, 頭部モデル内部および周囲の電界分布 について解析的に検討を行った。また, 同時に解析周 波数を $10,20,30 \mathrm{MHz}$ で変化させ，各周波数における 人体通信の特性の違いについて検討した。解析結果は, 異なる電磁界解析ソフトウェア (Schmid \& Partner 社 : SEMCAD X) で得られた結果とよく一致することを確 認している。さらに, 解析結果が妥当であることは, 本研究に類似した周波数や吸収境界などの解析条件下 で得られた計算結果[8]が，生体等価ファントムを用い た実験結果[17]とよく一致していることからも類推さ れる。

\section{1 二電極送受信機}

Fig. 5 (A) (C)に, 各周波数における二電極接触型の 送受信機を用いた場合の, 頭部モデル内部および周囲 の電界分布を示す。電界分布の観察面は, Fig. 2 に示 した送信受信機電極の中央部を横切る $\mathrm{zx}$ 面とした。周 波数の変化に対する電界分布の違いはほとんどみられ なかった。また, Table 3 に示すように, 電極の入力イ ンピーダンス $Z_{\text {in }}$ はいずれの周波数においても実部 50 $\Omega$, 虚部 $7 \Omega$ 程度となり, 変化は最大で $10 \%$ 程度であっ た。同様に, 送受信機間の伝送特性 $S_{21}$ も-64.3 - $64.8 \mathrm{~dB}$ の範囲であり，周波数による有意な差はないことが明 らかとなった。また, 二電極接触型の送信機を用いた 場合には, 送信機の信号電極とグラウンド電極の間に 集中して高周波電流が流れることによって, 送信機直 下の部分に比較的強い電界が分布し，人体内部を貫く 電界成分が伝送に大きく寄与することがわかった。

Table 3 Analysis results with two electrode transceiver.

\begin{tabular}{llll}
\hline Frequency $[\mathrm{MHz}]$ & $\operatorname{Re}\left(Z_{\text {in }}[\Omega]\right.$ & $\operatorname{Im}\left(Z_{\text {in }}\right)[\Omega]$ & $S_{21}[\mathrm{~dB}]$ \\
\hline 10 & 50.9 & -6.74 & -64.8 \\
20 & 48.2 & -7.00 & -64.3 \\
30 & 46.2 & -7.42 & -64.3 \\
\hline
\end{tabular}

\section{2 一電極送受信機}

Fig. 6 (A) (C)に，各周波数における一電極接触型の 送受信機を用いた場合の, 頭部モデル内部および周囲
の電界分布を示寸。電界分布の観察面は, Fig. 2 に示 した送信受信機電極の中央部分を横切る $\mathrm{zx}$ 面とした。 破線は頭部モデルと空間の境界を示している。二電極 構造の送受信機を用いた場合と同様に，周波数の変化 に対する電界分布の違いはほとんどみられなかった。 一方で, Table 4 に示すように, 電極の入力インピーダ ンス $Z_{\text {in }}$ の虚部は各周波数において大きく変化した。こ れは，送受信機電極モデルの回路基板と人体の間の浮 遊容量によって入力インピーダンス虚部がほぼ決定さ れることと，その浮遊容量による容量性リアクタンス が周波数によって大きく変化することに起因すると考 えられる。また，送受信機間の伝送特性 $S_{21}$ は $10 \mathrm{MHz}$ と $30 \mathrm{MHz}$ で $2.5 \mathrm{~dB}$ の差が生じた。これは, 周波数が 上がるにつれて電極の入力インピーダンスの虚部が減 少し，インピーダンス整合状態に近づき，信号の不要 な反射が低減されたためと考えられる。さらに, Fig. 6 からわかるように，一電極接触型の送信機を用いた場 合には，人体内部にはほとんど電界が浸透せず，人体 周囲を伝わっていく電界成分が伝送特性を決定するう えで支配的であると考えられる。ウェアラブル機器の 装用箇所が側頭部であることを考慮すると，人体内部 まで電界が浸透する状態は電界による生体曝露の点か ら好ましくない。このため, 生体に影響が少ないと考 えられる一電極構造が, 頭部装用型のウェアラブル機 器における電極構造として適していると考えられる。

Table 4 Analysis results with single electrode transceiver.

\begin{tabular}{llll}
\hline Frequency $[\mathrm{MHz}]$ & $\operatorname{Re}\left(Z_{\text {in }}\right)[\Omega]$ & $\operatorname{Im}\left(Z_{\text {in }}\right)[\Omega]$ & $S_{21}[\mathrm{~dB}]$ \\
\hline 10 & 19.3 & -8983 & -88.7 \\
20 & 18.4 & -4492 & -86.7 \\
30 & 17.2 & -2996 & -86.2 \\
\hline
\end{tabular}

\section{5 インピーダンス整合による伝送特性改善}

第 4 章において, 生体曝露の観点から一電極構造の 送受信機が頭部装用型のウェアラブル機器として適し ていることが示唆された。しかしながら，一電極構造 の送受信機によって得られる伝送特性は, 二電極構造 の場合に比較して $20 \mathrm{~dB}$ 以上小さな值となる。機器の 消費電力や電池寿命を考慮した場合には, 伝送効率の 低下は致命的である。このため, 本章では, 一電極構 造の送受信機の励振源および受信負荷と, 電極の入力 インピーダンスの間で整合をとることにより，伝送特 性の改善を図った[18]。解析周波数は, Wireless BAN の通信周波数である $21 \mathrm{MHz}$ および $32 \mathrm{MHz}$ に注目し, 


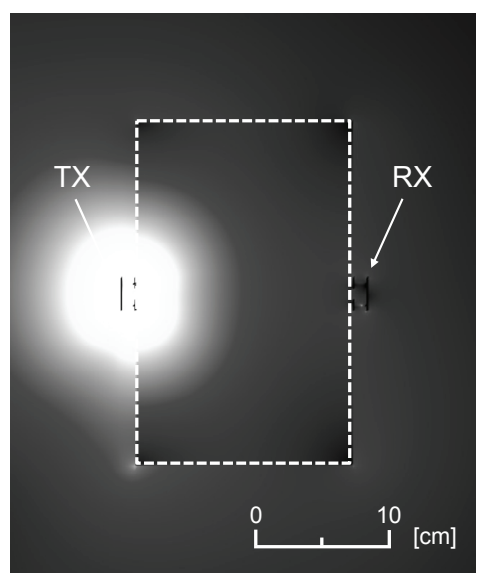

(A) $10 \mathrm{MHz}$

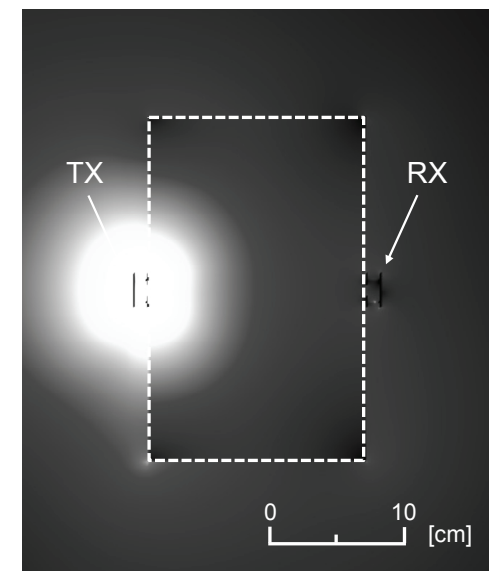

(B) $20 \mathrm{MHz}$

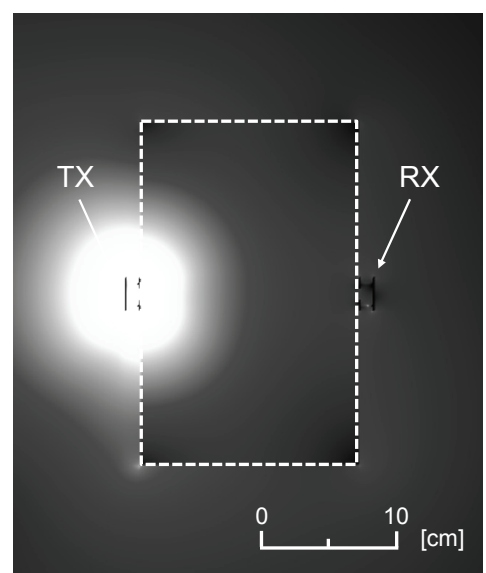

(C) $30 \mathrm{MHz}$

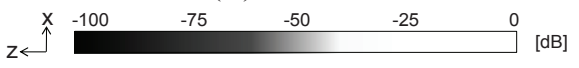

Fig. 5 Electric field distributions around and inside a head model with two electrodes transceiver.

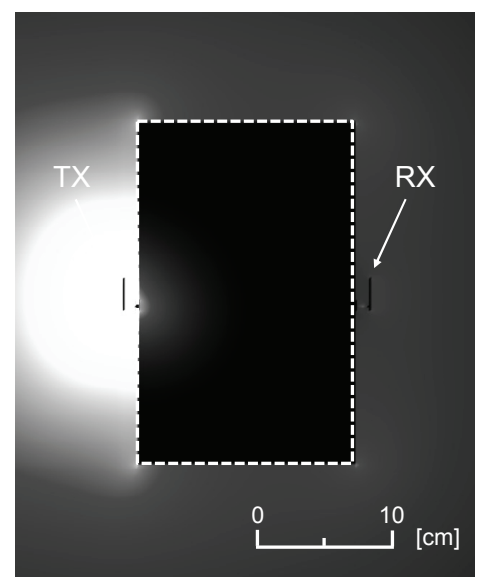

(A) $10 \mathrm{MHz}$

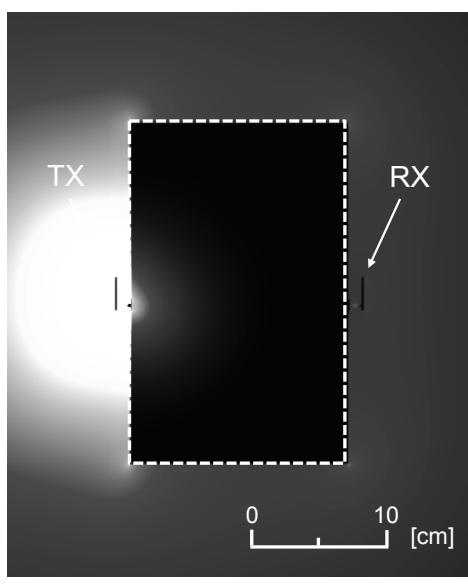

(B) $20 \mathrm{MHz}$

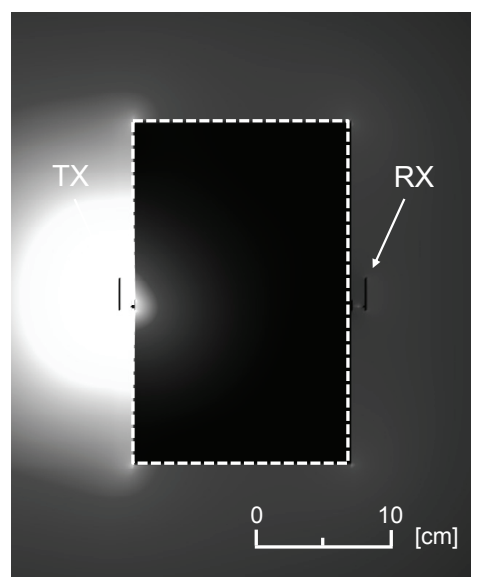

(C) $30 \mathrm{MHz}$

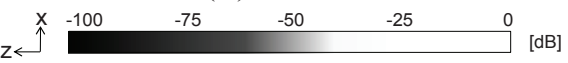

Fig. 6 Electric field distributions around and inside a head model with single electrode transceiver.

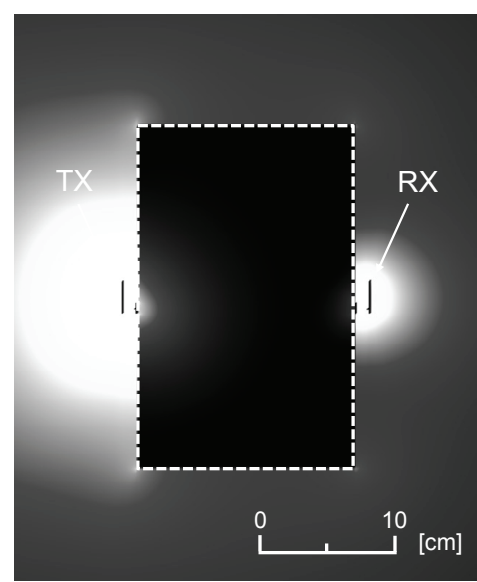

(A) $20 \mathrm{MHz}$

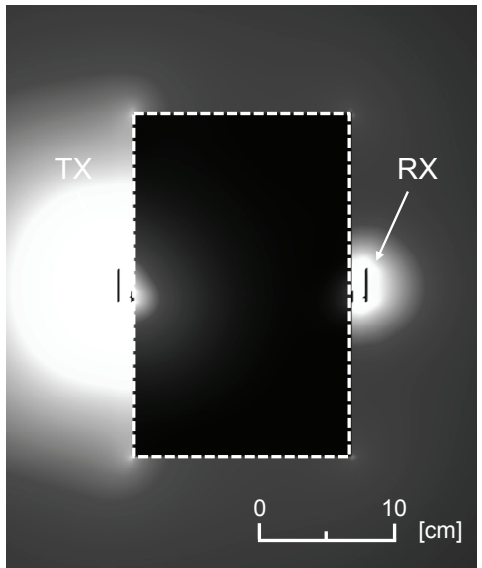

(B) $30 \mathrm{MHz}$

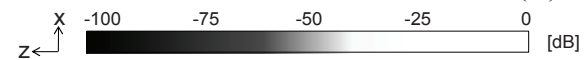

Fig. 7 Electric field distributions around and inside a head model with impedance matched single electrode transceiver. 
$20 \mathrm{MHz}$ および $30 \mathrm{MHz}$ とした。Table 5 に示寸電極の 入力のインピーダンスと整合をとるために, $20 \mathrm{MHz}$ においては, 送信機励振源の内部抵抗および受信負荷 として, $20 \Omega$ の抵抗に $35.7 \mu \mathrm{H}$ のインダクタンスを直 列に接続したものを用いた。また， $30 \mathrm{MHz}$ において は, 励振源の内部抵抗および受信負荷として，20 $\Omega$ の 抵抗に $15.9 \mu \mathrm{H}$ のインダクタンスを直列に接続したも のを用いた。これらの抵抗およびインダクタンスの利 用により, 電極入力インピーダンスの容量性リアクタ ンスをキャンセルし，インピーダンス実部において整 合をとることが可能となる。

Fig. 7 (A), (B)に，インピーダンス整合状態の一電極 接触型の送受信機を用いた場合の, 頭部モデル内部お よび周囲の電界分布を示す。 $20 \mathrm{MHz}, 30 \mathrm{MHz}$ の場合 ともに, インピーダンス整合の効果により受信機付近 の電界強度が大きくなっていることがわかる。また，

Table 5 に示寸ように, 送受信機間の伝送特性 $S_{21}$ は 20 MHz において-35.0 dB, $20 \mathrm{MHz}$ において-37.2 dB と 計算された。これは, Table 4 に示したインピーダンス 整合を考慮しない一電極構造の場合の $S_{21}$ に比較して, $50 \mathrm{~dB}$ 程度大きな值であり, 励振源および負荷に最適 なインピーダンスを選択することにより大幅に伝送特 性が改善可能なことが確認された。さらに, Table 3 に 示した二電極構造の場合と比較しても $S_{21}$ は 27 29 dB 向上することが明らかになった。加えて, Fig. 7 から わかるように, インピーダンス整合をとった状態にお いても，人体内部にはほとんど電界が浸透せず，人体 周囲を伝わる電界成分が支配的であることがわかる。 これは, 電極が単に人体に対してのみインピーダンス 整合をとっているのではなく, 人体と周囲の空間の両 者の合成に対して整合をとっているためである。以上 の結果より, 人体頭部に装着されたウェアラブル機器 間の通信においては，生体に対する電磁的な曝露が小 さい伝送メカニズムを有する一電極構造の送受信機を 用いて，高い伝送特性を実現できることが明らかにな った。

Table 5 Analysis results with single electrode transceiver.

\begin{tabular}{llll}
\hline Frequency $[\mathrm{MHz}]$ & $\operatorname{Re}\left(Z_{\text {in }}\right)[\Omega]$ & $\operatorname{Im}\left(Z_{\text {in }}\right)[\Omega]$ & $S_{21}[\mathrm{~dB}]$ \\
\hline 20 & 18.4 & -4492 & -35.0 \\
30 & 17.2 & -2996 & -37.2 \\
\hline
\end{tabular}

\section{6 生体に対する安全性}

無線通信の受信モジュールの限界感度は，-70dBm 程度であるのが一般的である[19]。第 5 章で検討した 一電極送受信機の場合には, 励振源において $0.5 \mathrm{~V}$ 程 度を入力したときに受信限界感度を満足する。このと き, 電界が生体に与える影響を確認するため SAR (Specific Absorption Rate) を計算したところ, 頭部組織 $10 \mathrm{~g}$ あたりの局所 SAR の最大值は $3.62 \times 10^{-4} \mathrm{~W} / \mathrm{kg}$ とな った。これは総務省の電波防護指針[20]に示される局 所吸収制限の 5000 分の 1 以下であり, 電磁波の熱作用 という点で, 本技術は生体に対して安全と考えられる。

\section{7 まとめ}

本稿では, 補聴器等の頭部に装用するウェアラブル 機器間の人体通信に着目し送受信機の電極構造および 信号周波数の变化による伝送メカニズムの差異につい て検討した。検討の結果，10 30 MHz の範囲での周波 数変化に対しては, 送受信機電極の入力インピーダン 不特性，送受信機間の伝送特性，人体周囲の電界分布 に顕著な変化はないことが明らかになった。また，送 受信機に二電極構造を用いた場合には，送信機直下の 部分に比較的強い電界が分布し, 人体内部を電界が貫 く状態で送信機から受信機へ伝搬することが確認され た。一方で, 送受信機に一電極構造を用いた場合には, 人体内部にはほとんど電界が浸透せず，人体周囲を電 界が伝搬して伝送が行われることが確認された。以上 の検討より, 生体曝露の点で影響が少ないと考えられ る一電極構造の送受信機について, インピーダンス整 合による伝送特性の改善を試みた。その結果, $20 \mathrm{MHz}$ において $S_{21}=-35.0 \mathrm{~dB}$ の高い伝送特性を実現できるこ とを示した。本研究において明らかにされた頭部装用 機器の伝送メカニズムは, 補聴器などの福祉機器だけ でなく, ヘッドセットやへッドマウントディスプレイ といった, 様々な頭部装着型機器間の人体通信システ ム設計において重要な知見になると考えられる。

\section{謝辞}

本研究の一部は日本学術振興会特別研究員奨励費 (25・5924）の補助を受けて行われた。ここに謝意を表 する。

(2014 年 4 月 2 日受付) 


\section{参考文献}

[1] Huan-Bang Li, K. Takizawa, R. Kohno, "Trends and Standardization of Body Area Network", Proceeding of the 1st European Wireless Technology Conference, pp.1-4, 2008.

[2] T. G. Zimmerman: "Personal Area Networks (PAN):NearField Intra-Body Communication”, M.S.thesis, MIT Media Laboratory, 1995.

[3] T. G. Zimmerman: "Personal Area Networks: Near-Field Intra-Body Communication", IBM Systems Journal, Vol. 35, No. 3 \& 4, pp. 609-617, 1996.

[4] K. Fujii, M. Takahashi, K. Ito, K. Hachisuka, Y. Terauchi, Y.Kishi, K. Sasaki and K. Itao, "Study on the TransmissionMechanism for Wearable Device Using the Human Body as aTransmission Channel", IEICE Trans., Vol. E88-B, No.6, pp.2401.2410, 2005.

[5] K. Fujii, M. Takahashi, K. Ito, "Electric Field Distributions of Wearable Devices Using the Human Body as a Transmission Channel", Antennas and Propagation, IEEE Transactions on Vol. 55, No. 7, pp.2080-2087, 2007.

[6] 土井謙之, 西村篤久, “人体を伝送路と寸る高信頼性通 信方式”，松下電工技報, Vol.53, No.3, pp.72-76, 2005.

[7] K. Hachisuka, Y. Kishi, Y. Hayashi, K. Sasaki, "Signal Transmission Modeling of the Intrabody Communication and Experimental Analyses", Journal of Japan Institute of Electronics Packaging, Vol.10, No.6, pp.462-468, 2007.

[8] 村松大陸, 山本隆彦, 越地福朗, 越地耕二, 佐々木健, “インピーダンス整合を考慮した人体通信送信機の電 極設計と周辺電界に関する検討”, ライフサポート学会 誌, Vol.24, No.7, pp.70-78, 2012.

[9] 村松大陸, 山本隆彦, 越地福朗, 越地耕二, “人体通信 用受信機の電極構造に関する検討”, 日本 AEM 学会誌, Vol.19, No.2, pp.354-359, 2011.

[10] 松代直樹, 他, “人工内耳と補聴器の両耳装用における 両耳聴効果について語音聴取能 (67-S 語表, Japanese HINT）に関寸る検討一”, 日本耳鼻咽喉科学会会報, Vol.106, No.3, pp.211-219, 2003.

[11] International Telecommunication Union (http://www.itu.int/en/pages/default.aspx)

[12] IEEE Standard for Local and metropolitan area networks Part 15.6: Wireless Body Area Networks, IEEE Computer Society, 2012.

[13] 設計のための人体寸法データ集. 生命工学工業技術研 究所編. 人間生活工学研究センター. 日本出版サービ ス, ISBN4-88922-093-3 C3040 P4635E, 1996.

[14] Gabriel, R W Lau, C Gabriel, "The dielectric properties of biological tissues: II. Measurements in the frequency range $10 \mathrm{~Hz}$ to $20 \mathrm{GHz}$ ", Phys. Med. Biol. 41, pp.2251-2269, 1996.

[15] IFAC website (http://niremf.ifac.cnr.it/tissprop/)
[16] T. Nagaoka, S. Watanabe, K. Sakurai, E. Kunieda, S. Watanabe, "Development of realistic high-resolution whole-body voxel models of Japanese adult male and female of average height and weight and application of models to radio-frequency electromagnetic-field dosimetry", Physics in Medicine and Biology, Vol.49, pp.1-15, 2004.

[17] D. Muramatsu, T. Yamamoto, F. Koshiji, K. Koshiji, "Structural Design of Transmitter and Receiver Electrodes for Improvement of Transmission Characteristics in Human-Body Communication", International Conference on Electronics Packaging 2011, pp.114-119, 2011.

[18] F. Koshiji, et. al., "Proposal and Investigation of Unbalanced Dipole Antenna with Semicircular and Trapezoidal Radiators for UWB Radio", Journal of Japan Institute of Electronics Packaging, Vol. 10, No. 3, pp. 200-211, May 2007.

[19] A. Sugiura: "Basics of Bluetooth Communication," Interface, Vol.27, No. 8, pp. $60-63,2001$.

[20］総務省電波防護指針(http://www.tele.soumu.go.jp/) 